\title{
Engineering approaches for road construction projects and determination of geotechnical design parameters: Road network improvement of northern Iraq
}

\author{
Mustafa Can Canoglu \\ Faculty of Engineering and Architecture, Environmental Engineering Department, Sinop University. \\ Corresponding Author:mccanoglu@sinop.edu.tr
}

$\begin{array}{ll}\text { Submitted } & : 17 / 10 / 2020 \\ \text { Revised } & : 07 / 06 / 2021 \\ \text { Accepted } & : 27 / 06 / 2021\end{array}$

\begin{abstract}
Transport in northern Iraq becomes an important issue in terms of trading due to its geographical position. Road construction between Darbandikhan and Kalar villages in the northern part of Iraq is crucial for the connection of Erbil and Suleymaniye to northeast. The planned road construction requires a detailed environmental and geotechnical study in order to determine geo-engineering parameters of ground conditions. For this purpose, this study is carried out to highlight the engineering geological and geotechnical features considering the groundwater conditions of the Darbandikhan-Kalar road route section. In this context, field and laboratory works were performed along the projected route. Within the scope of field studies, an engineering geology map was generated, a suitable routing was specified, and drilling and in-situ testing was completed. Seven boreholes and total of 196,5 m geotechnical purposed drilling works were performed along the planned route section. The core samples obtained from drilling works are utilized for laboratory testing. As a result of this study information about the bearing capacity, slope stability and basic soil parameters were determined and no problems were encountered.
\end{abstract}

Keywords: Darbandikhan - kalar road; Road projection; Geotechnical design.

\section{INTRODUCTION}

Due to the varying geostrategic conditions, northern Iraq became an important passage and the existing trade routes fail to satisfy the needs of merchants and the local people. For this reason, improving the road network of northern Iraq is important. In this study, Darbandikhan-Kalar road project which consists of the road between Darbandikhan and Kalar villages in the northern part of Iraq is evaluated in terms of geotechnical assessment and engineering characterization. This road is projected to be $18+480 \mathrm{~km}$ in length and would connect from Darbandikhan to Kalar. 

ment of northern Iraq

Geotechnical design and optimization of road constructions have been studied by many researchers from different perspectives (Eldin, 2002, Santoni et al., 2001, Younussa et al., 2008, Sadek et al., 2000, and Canogluet al., 2017). In general, these studies consisted of the geotechnical design of a road and involved complex processes including empirical engineering estimates. A geotechnical engineer who works in a highway project has to consider all potential risks and their prevention within the routing under study. In the Darbandikhan-Kalar road project, geotechnical site investigations have been conducted precisely prior to the projecting stage in order to foreseen the potential engineering problems and analyse their remediation costs. Within this context, a number of boreholes were drilled, and in-situ and laboratory tests were implemented in order to evaluate the geotechnical design parameters. In addition, the groundwater level surveys have been measured to take precautions for the unexpected events.

\section{General Characteristics of the Project Area}

Study area is located in northeast of Iraq near Suleymaniye region. The climate in north of the study area is generally coastal, and the south is a typical desert climate. The summers in the project area are hot and dry; the winters are relatively cold and sometimes rainy. The northern part of the study area is generally snowy due to the mountainous topography. The Darbandikhan-Kalar road is an important link for the transport of northern Iraq in terms of trade and alternative routing to Musul to Turkey (Fig. 1).

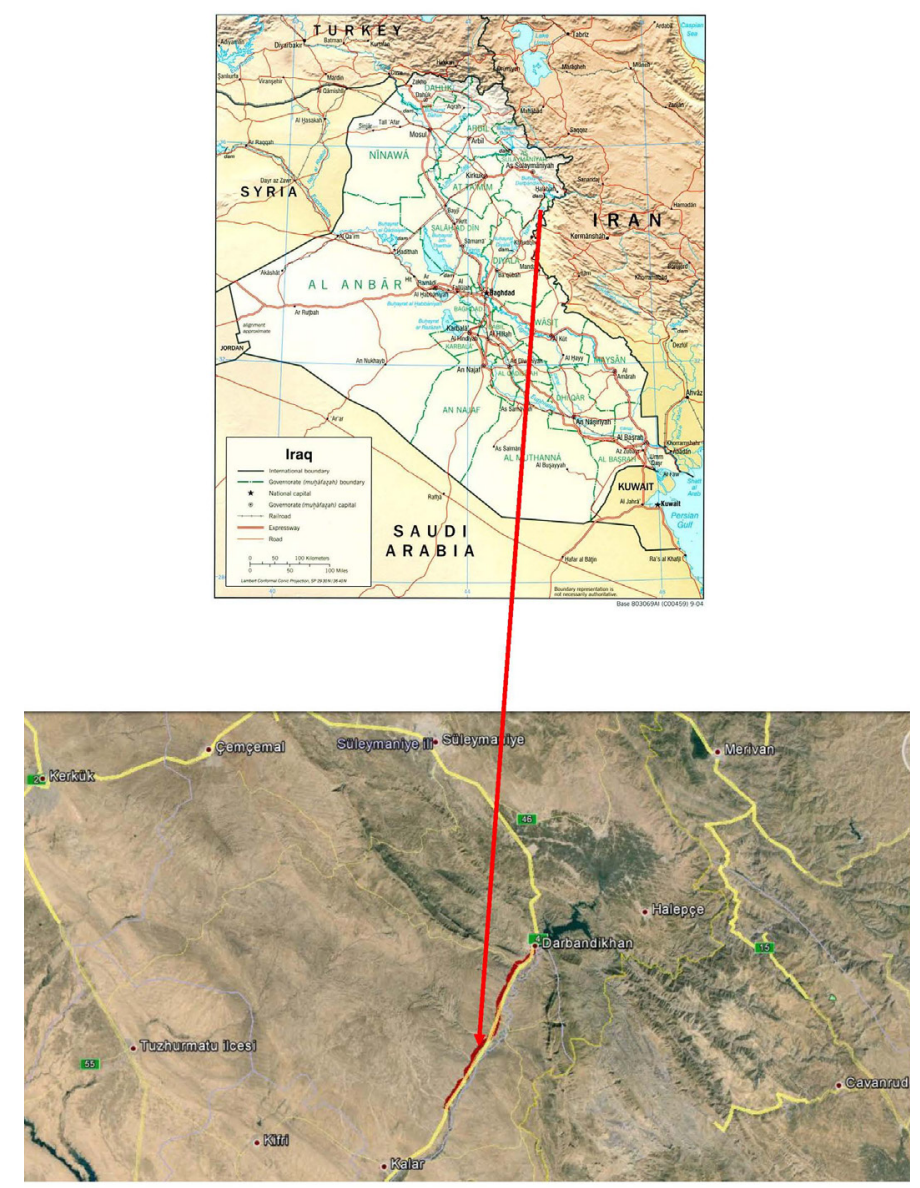

Figure 1. Site location map of the study area. 
The Rovia-Gopal road is $18,4 \mathrm{~km}$ in length and projected two lanes. There are two hydraulic bridges designed on the route between St:0+000 and 5+500. The hydraulic bridges are located at St:1+085 and St:5+630. Both of the hydraulic bridges have been designed with 8 spans and with a length of $350 \mathrm{~m}$. 21 hydraulic box culverts have been also designed throughout the route.

\section{Regional Geology of the Study Area}

The surface geology of Iraq roughly reflects its morphology. Generally, the youngest sediments (Quaternary and Neogene) lie within the central depression, while the flanks expose older strata of Paleogene to Paleozoic age (Norouzi, et al., 2002). The geology of the desert area to the SW of the Euphrates River is generally characterized by NE dipping strata which are slightly more inclined than the land surface (Hany Al-Hmedawy, 2008). However, in W Iraq near Rutba town the strata dip to the west away from the axis of a major ENE-WSW trending anticlinorium in which rocks are as old as Permian outcrop. The erosion of the crest of the anticlinorium has created the Ga'ara depression. The geology of the Mesopotamian depression is produced by a complex system of river channels, levees, flood plain, marshes, khor-lagoon, and deltas, bordered on both sides by alluvial fans (Hany AlHmedawy, 2008).

The Jezira area in NW Iraq is dominated by a massive uplift (Tayarat). Middle Miocene sabhka deposits, exposed in the core of the uplift, are flanked in the E, N, and W by Upper Miocene clastics. The south erosion by the Euphrates River has exposed Oligocene and Lower Miocene carbonates along tight anticlinal structures controlled by E-W faults. The foothills NE of the Mesopotamian depression comprise narrow (roughly 5-10km wide) anticlines. Upper Miocene to Pleistocene molasses sediments (such as sandstones, shales, and conglomerates) or Middle Miocene evaporates are exposed in their cores. Some higher amplitude anticlines within the zone such as Sinjar and QaraChauq have exposures of Paleogene and locally Upper Cretaceous formations in their cores. The foothill anticlines are usually asymmetrical towards the SW and are often associated with decollement thrust faults (controlled by Middle Miocene evaporates) in the area south of the Lesser Zap River. In N Iraq along the Turkish border, Paleozoic to Cretaceous rocks are exposed in the cores of tight anticlines bounded by thrust faults. Along the Iranian border, there are thrust sheets of sedimentary and igneous rocks which were formed in the Neo-Tethyan oceanic domain. The

The lowest of these comprise radiolarian chert and volcanoes which were thrust over the shelf carbonates of the Arabian Plate during the Late Cretaceous. The project area falls into the Low Folded Zone (LFZ) as seen from Figure 2. The LFZ from physiographical point of view is known as the Foothills Province, which is situated between the High Mountain and the Mesopotamian Plain Provinces of Iraq. Both the north eastern and southwestern boundaries are marked by distinct morphologic breaks in slope. And they represent distinct tectonic lines. Consequently, the name of the zone has geological expression rather than physiographic. The LFZ covers about $56930 \mathrm{~km}^{2}$. It forms a wide hilly terrain oriented NW-SE and E-W, with average width of about $160 \mathrm{Km}$ and length of $400 \mathrm{Km}$, in addition to its south-eastern extent, which forms very narrow and discontinues strips, up to 15 $\mathrm{Km}$ width (discontinuous within the Iraqi territory), following the Iraqi-Iranian international borders. 


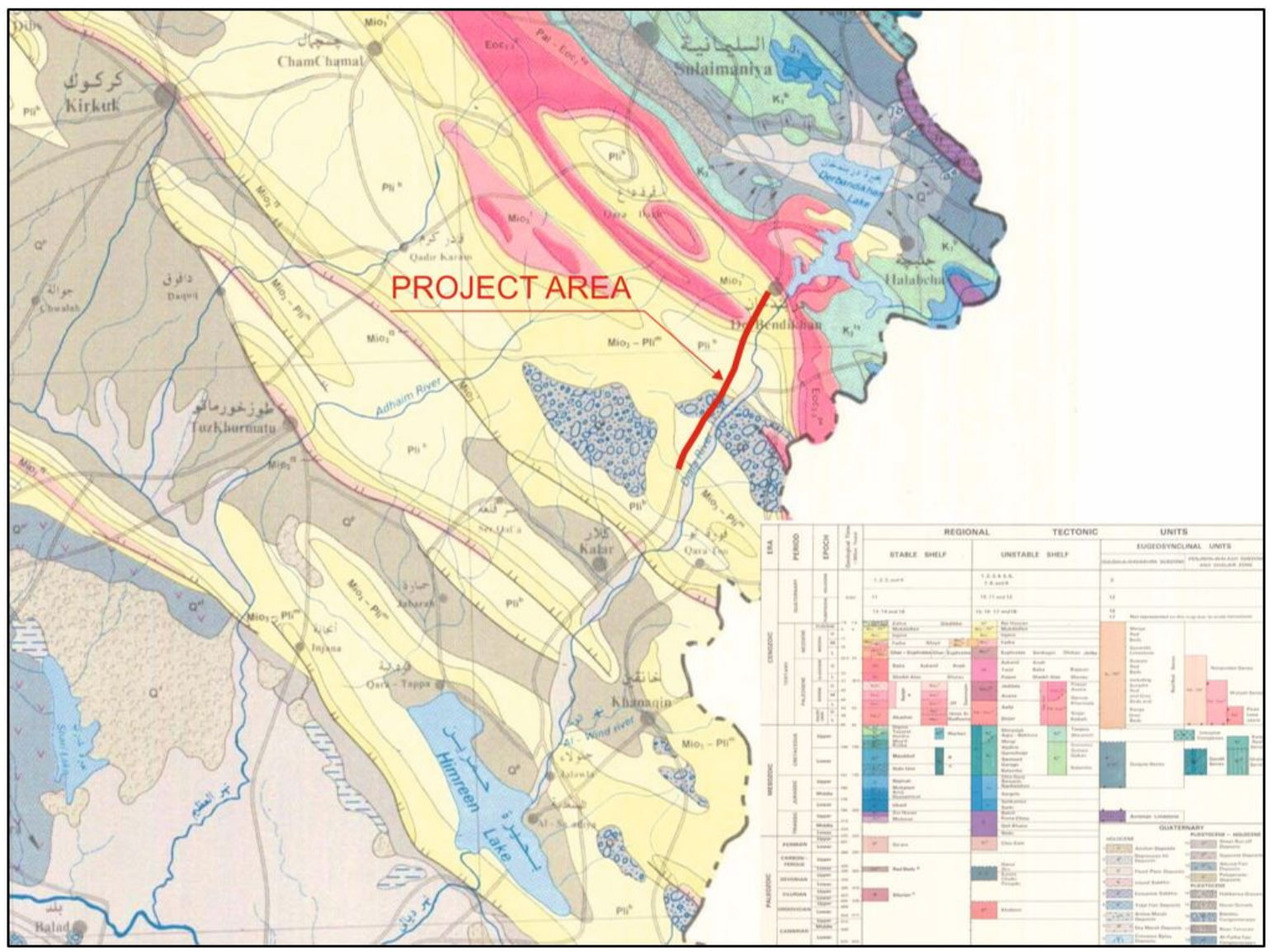

Figure 2. General geology map of the study area.

In the investigation area (Darbandikhan-Kalar road routing) Upper Fars (Injana) formation forms the foundation geological units from the start to St: $7+800 \mathrm{Km}$ of the road route. The foundation units consist of cyclic deposits of clastic materials. The cycle starts with claystone, pebbly sandstone, and thick layers of the conglomerate. Conglomerates are lithified by clay and calcareous cement. Sandstone and claystone layers are well lithified and have hard consistency.

Tectonically, Iraq is located in a relatively active seismic zone at the tectonically active northern and eastern boundaries of the Arabian Plate. Although Iraq is seemingly secure from seismic hazards, seismic observations indicate otherwise. Earthquakes are likely to happen and may cause substantial damage, especially in NE Iraq and in the Mesopotamian Plain due to liquefaction of Quaternary sediments. It is therefore important to take into consideration seismic parameters in future design of large buildings. The investigation area is located at moderateminor damage zone; therefore, horizontal earthquake acceleration shall be taken as $0,3 \mathrm{~g}$ for structures and $0,15 \mathrm{~g}$ for slope stability analysis (Fig. 3). 


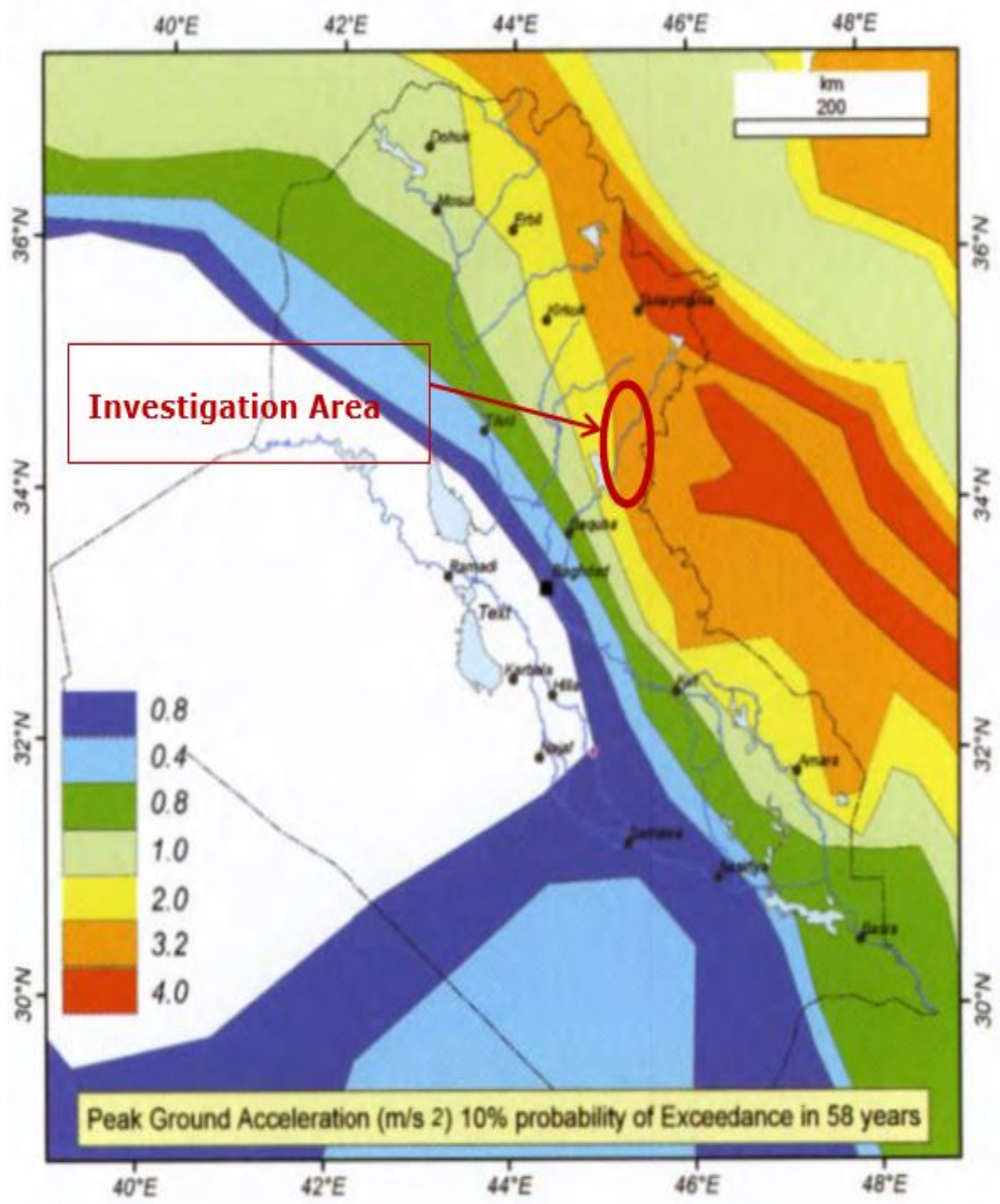

Figure 3. Seismic zoning map of the study area.

\section{METHODOLOGY}

In road construction projects, the selection of routing corridor follows complex processes. These processes require the optimization of many different parameters and necessitate heuristic engineering approaches. The methodology followed in this particular project, in which the Darbandikhan-Kalar road project is represented, uses a workflow diagram in order to express the processes more subjectively than typical studies (Fig. 4). 


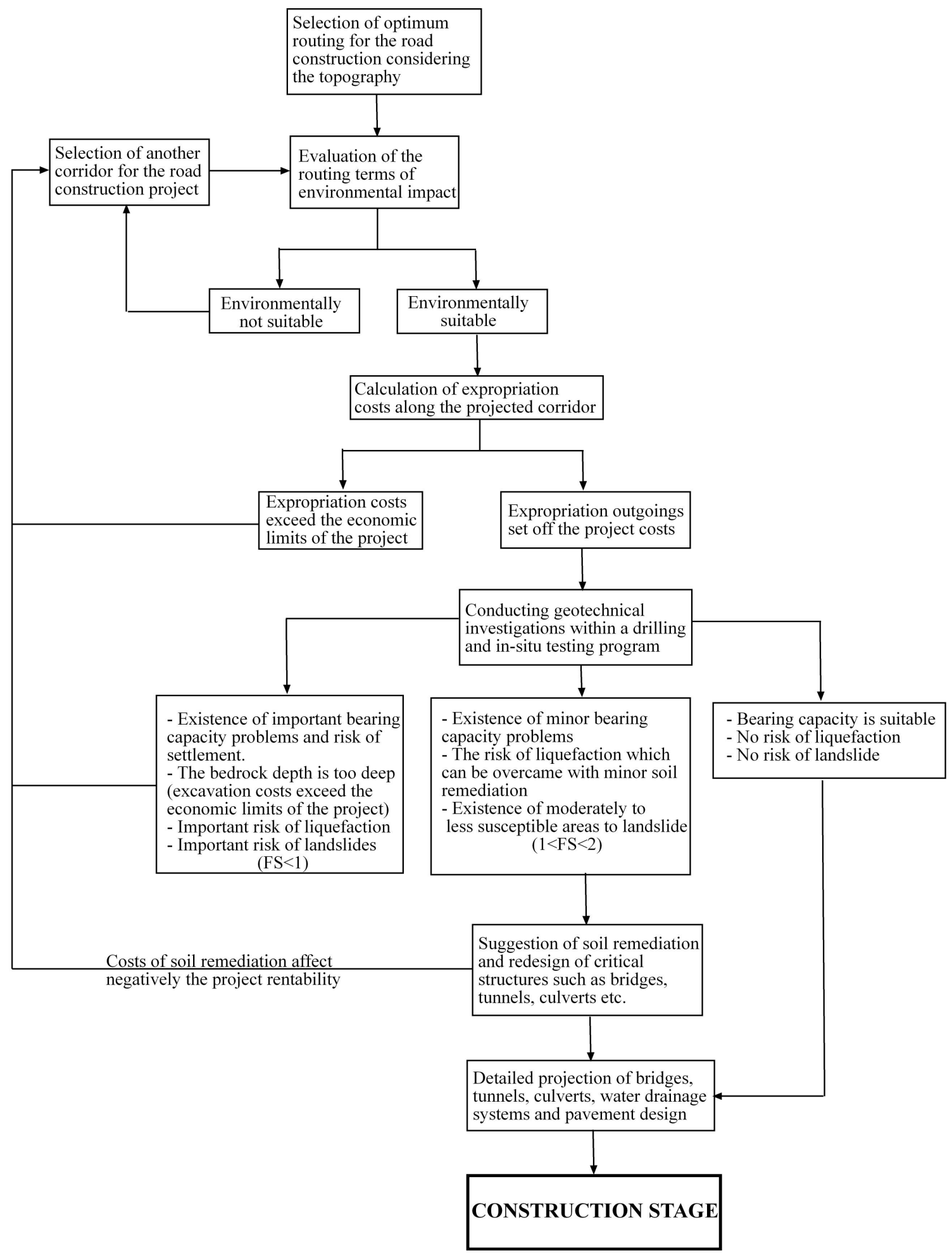

Figure 4. Workflow diagram of decision making processes in the design of roads (FS: factor of safety) 
Before the detailed evaluation of the Darbanbdikhan-Kalar road, an optimum routing is selected considering the topographic features. This selected route is evaluated in terms of environmental impact. If the route is environmentally suitable and the expropriation costs of the project are set, preliminary geotechnical investigations are conducted based on a drilling and in-situ testing program. During the preliminary geotechnical investigations, bearing capacity, liquefaction, landslide risks are analysed in order to mitigate the potential risks and to reduce the construction costs. In this context, boreholes were drilled and the in-situ tests such as Standard Penetration Test (SPT) and Lugeon tests (water pressure test) were performed in the boreholes. The hydraulic conductivity of the geological formation under variable hydraulic head was determined by the Lugeon tests. Additionally, laboratory tests were implemented on core samples taken from the drilled boreholes. In this way, crucial data such as bearing capacity and liquefaction potential of the ground along the routing were obtained, and the landslide risks were revealed. If the bearing capacity was not suitable and there was a risk of settlement and or existence of liquefaction and land sliding problems, ground remediation could be suggested considering the project viability. After all these stages, bridges, culverts, tunnels, water drainage systems, and pavement design were projected in detail, and then construction stage initiated.

\section{Geotechnical Characterization of the Routing}

Throughout the planned routing, geotechnical investigations and engineering geology studies have been conducted. In order to determine the stratification and engineering properties of subsurface soil, a drilling program has been prepared and locations of trial pits have been determined along the projected corridor. The geological profile is created according to the data obtained from boreholes, trial pits, laboratory test results, and reconnaissance of the site. A total of seven boreholes have been drilled and 10 trial pits have been excavated along the planned road in the investigation area to reveal the geotechnical conditions of the soil and rock units. The depth of boreholes drilled along the routing varies between 15 and $31 \mathrm{~m}$ and a total of $166,5 \mathrm{~m}$ of boreholes are drilled. Rotary drilling method is utilized for all the boreholes.

In-situ testing was also implemented in the drilled boreholes. In this context, Standard Penetration Tests (SPT) were performed, and undisturbed samples (UD) were taken from suitable soil levels of the boreholes. Rock core specimens $(\mathrm{Kk})$ have been taken at rock (conglomerate and etc.) levels.

Groundwater levels were measured in the drilled boreholes of the investigation site. Measurements were implemented during drilling and on the completion of drilling. During drilling, groundwater was measured in the morning and evening or in every shift change-over and recorded on the related logs. On completion of drilling, groundwater levels were also measured and logged once a day.

A number of laboratory tests have been performed on the disturbed soil samples taken from the boreholes and trial pits such as Atterberg limit tests, sieve analysis, specific gravity tests, standard proctor test, CBR (Californian Bearing Ratio) tests, and several chemical tests. Unconfined compression tests have been performed on undisturbed samples taken from Sandstone/Claystone layers.Conglomerate layers are usually clay-carbonate cemented and the clay-carbonate is washed by drilling water. So, the cores are usually observed as gravel like fragments. Therefore, adequate samples with suitable size for laboratory experiments couldn't be obtained from conglomeratic levels.

The unconfined compression strength natural unit weight and dry unit weight of the undisturbed soil samples taken from the boreholes are shown in Table 1. 
Table 1. Laboratory test results of the soil samples handled from the boreholes.

\begin{tabular}{|c|c|c|c|c|c|c|c|}
\hline \multirow[t]{2}{*}{ Borehole no. } & \multirow{2}{*}{$\begin{array}{c}\text { Depth } \\
\text { (m) }\end{array}$} & \multicolumn{2}{|c|}{$\begin{array}{c}\text { Unconfined compressive } \\
\text { strength }\end{array}$} & \multicolumn{2}{|c|}{ Natural unit weight } & \multicolumn{2}{|c|}{ Dry unit weight } \\
\hline & & (MPa) & $\left(\mathrm{kgf} / \mathrm{cm}^{2}\right)$ & $\left(\mathrm{gr} / \mathrm{cm}^{3}\right)$ & $\left(\mathrm{kN} / \mathrm{m}^{3}\right)$ & $\left(\mathrm{gr} / \mathrm{cm}^{3}\right)$ & $\left(\mathrm{kN} / \mathrm{m}^{3}\right)$ \\
\hline \multirow{4}{*}{ BH - 2} & $12,50-13,00$ & 5,48 & 55,89 & 2,460 & 24,13 & 2,460 & 24,13 \\
\hline & $13,50-13,70$ & 4,17 & 42,51 & 2,459 & 24,11 & 2,459 & 24,11 \\
\hline & $16,50-17,00$ & 4,24 & 43,22 & 2,459 & 24,11 & 2,459 & 24,11 \\
\hline & $20,00-20,50$ & 6,54 & 66,72 & 2,364 & 23,18 & 2,364 & 23,18 \\
\hline \multirow{4}{*}{$\mathrm{BH}-3$} & $6,00-6,20$ & 7,95 & 81,09 & 2,430 & 23,83 & 2,430 & 23,83 \\
\hline & $8,00-8,20$ & 12,40 & 126,48 & 2,417 & 23,70 & 2,417 & 23,70 \\
\hline & $11,00-11,50$ & 6,61 & 67,41 & 2,452 & 24,05 & 2,452 & 24,05 \\
\hline & $24,00-24,50$ & 14,52 & 148,05 & 2,530 & 24,81 & 2,530 & 24,81 \\
\hline \multirow{2}{*}{$\mathrm{BH}-5 \mathrm{~B}$} & $5,80-6,00$ & 1,74 & 17,73 & 2,409 & 23,62 & 2,409 & 23,62 \\
\hline & $8,00-8,20$ & 1,11 & 11,31 & 2,483 & 24,35 & 2,483 & 24,35 \\
\hline \multirow{2}{*}{$\mathrm{BH}-6$} & $13,00-13,80$ & 6,49 & 66,15 & 2,406 & 23,59 & 2,406 & 23,59 \\
\hline & $18,00-18,50$ & 4,21 & 42,95 & 2,493 & 24,45 & 2,493 & 24,45 \\
\hline
\end{tabular}

The optimum moisture content (OMC) and maximum dry density (MDD) values obtained by the standard proctor tests and the CBR test results are shown in Table 2.

Table 2. Laboratory tests results of the samples obtained from trial pits.

\begin{tabular}{|c|c|c|c|c|c|c|c|c|c|c|c|c|c|c|c|c|}
\hline \multirow{3}{*}{ 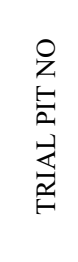 } & \multicolumn{2}{|c|}{ Proctor } & \multicolumn{3}{|c|}{$\% \mathrm{CBR}$} & \multicolumn{4}{|c|}{ Grain size distribution } & \multicolumn{3}{|c|}{ Atterberg limits } & \multirow{3}{*}{ 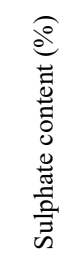 } & \multirow{3}{*}{$\frac{e^{o}}{e_{0}^{0}}$} & \multirow{3}{*}{$\begin{array}{l}\text { 胥 } \\
\text { 壱 }\end{array}$} & \multirow{3}{*}{ 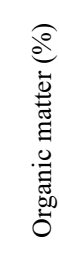 } \\
\hline & \multirow{2}{*}{$\frac{\delta^{o}}{\sum_{0}^{0}}$} & \multirow{2}{*}{ 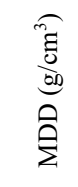 } & \multirow{2}{*}{ is } & \multirow{2}{*}{$\tilde{i}$} & \multirow{2}{*}{ 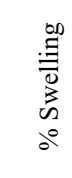 } & $\begin{array}{l}\bar{\Xi} \\
\stackrel{\mathbb{J}}{0}\end{array}$ & 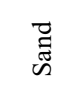 & 咅 & 胥 & ב & $\overrightarrow{2}$ & $\bar{a}$ & & & & \\
\hline & & & & & & $(\%)$ & $(\%)$ & $(\%)$ & $(\%)$ & $(\%)$ & $(\%)$ & $(\%)$ & & & & \\
\hline TP-1 & 13 & 1,901 & 4,59 & 5,02 & 1,09 & 14,6 & 12,4 & 41,8 & 31,3 & 27,5 & 14,4 & 13,1 & 0,07 & 18,8 & 7,6 & 0,49 \\
\hline TP-2 & 10,6 & 1,969 & 4,81 & 5,07 & 0,73 & 17,3 & 31,5 & 40,5 & 10,8 & 24,4 & 18 & 6,4 & 0,037 & 20,9 & 7,4 & 1,53 \\
\hline TP-3 & 12,4 & 1,857 & 2,83 & 3,31 & 0,86 & 6,2 & 38,2 & \multicolumn{2}{|c|}{55,6} & 27,3 & 15,1 & 12,2 & 0,087 & 27,3 & 7,6 & 1,02 \\
\hline TP-4 & 12,6 & 1,794 & 2,84 & 2,62 & 1,8 & 3,5 & 26,8 & 43,6 & 26,1 & 27,5 & 15,1 & 12,4 & 0,112 & 23,4 & 7,5 & 1,02 \\
\hline TP-5 & 12,5 & 1,908 & 4,25 & 3,91 & 0,69 & 43 & 18,6 & 19,9 & 18,6 & 35,5 & 17,5 & 18 & 0,077 & 20,2 & 7,6 & 1,77 \\
\hline TP-6 & 11,1 & 1,898 & 6,18 & 6,14 & 2,17 & 16,7 & 20,6 & 39 & 23,7 & 29,2 & 15,7 & 13,5 & 0,121 & 19,9 & 7,4 & 1,42 \\
\hline TP-7 & 13,5 & 1,881 & 4,62 & 5,2 & 0,6 & 3,3 & 12,7 & \multicolumn{2}{|c|}{84} & 30,2 & 13,9 & 16,3 & 0,023 & 20,2 & 7 & 0,52 \\
\hline TP-8 & 12,1 & 1,959 & 1,71 & 1,7 & 0,02 & 28,7 & 2,5 & 47,1 & 21,7 & 27,7 & 14,8 & 12,9 & 0,095 & 16,4 & 7,4 & 1,65 \\
\hline TP-9 & 11,7 & 1,773 & 4,75 & 5,22 & 1,51 & 0,3 & 14,5 & \multicolumn{2}{|c|}{85,2} & 27 & 15,1 & 11,9 & 0,068 & 16 & 7,5 & 1,21 \\
\hline TP-10 & 13,2 & 1,863 & 4,01 & 4,1 & 0,57 & 0,4 & 14 & \multicolumn{2}{|c|}{85,6} & 27,9 & 15,7 & 12,2 & 0,106 & 18,8 & 7,6 & 1,59 \\
\hline
\end{tabular}


Geotechnical assessments of culvert and cut \& fill sections are evaluated in order to predict the potential problems of the construction stage. Bearing capacity and settlement analysis for culvert sections were performed for the culverts having the largest dimension to ensure a safe design.

Fill slopes are designed to be $2 \mathrm{~h} / 1 \mathrm{v}$ ( 2 horizontal / 1 vertical), and cut slopes are $3 \mathrm{~h} / 2 \mathrm{v}$. The main rock types at the site are conglomerate, sandstone, claystone, and their altered residuals.

\section{Bearing Capacity Calculations of Culverts}

In geotechnical literature, a number of calculation methods of the bearing capacity of the foundation are introduced by many researchers such as Hansen (1970), Meyerhof (1963), and Vesic (1975). These bearing capacity calculation and analysis methods are detailed in Equation (1) and Equation (2):

$$
q_{u l t}=\mathrm{c} N_{c} s_{c} d_{c}+\mathrm{q} N_{q} s_{q} d_{q}+0,5 \gamma B N_{\gamma} s_{\gamma} d_{\gamma} r_{\gamma}
$$

$N_{c}, N_{\gamma}$, and $N_{q}$ are the bearing capacity factors, $s_{c}, s_{q}$, and $s_{\gamma}$ are shape correction factors, $B$ is the foundation width, and $d_{c}, d_{q}$, and $d_{\gamma}$ are depth correction factors.

A reduction factor has been suggested to be utilized for large foundation widths (B $>2 \mathrm{~m}$ ) by both Vesic (1969) and De Beer (1965) in order to limit the value of ultimate bearing capacity. (qult.) The calculation of this reduction factor $\left(r_{\gamma}\right)$ introduced by Bowles (1996) is shown in Equation(2):

$$
r_{\gamma}=1-0,25 \log (B / 2)
$$

For the calculation of bearing capacity, the culvert having the biggest dimension $\left(4 \mathrm{~m}^{2}\right.$ square shaped box culvert) is considered to be a safe design. In this context, idealized soil profile of St:2+248 culvert is formed using the borehole information of $\mathrm{BH}-5 \mathrm{~B}$ and its geological profile. The idealized soil profile of the borehole $\mathrm{BH}-5 \mathrm{~B}$ is composed of 0,0-4,0m conglomerate layer, and beneath this layer there is sandstone.

The bearing capacity analysis is conducted assuming that conglomerate layer is beneath the foundation. Even then, bearing capacity or settlement problems are not encountered. The angle of internal friction $(\varphi)$ value obtained from triaxial compressive strength and the unit weight value $(\gamma)$ from the laboratory tests were considered at design as $\varphi=36^{\circ}$ and $\gamma=21,0 \mathrm{kN} / \mathrm{m}^{3}$. For the culvert St: $2+248$, the width is $\mathrm{B}=3,5 \mathrm{~m}$ and the length is $\mathrm{L}=45,0 \mathrm{~m}$ length (Table 3). The calculation of thereduction factor for the geometry of theculvert St: $2+248$ is given in Equation(3).

$$
r_{\gamma}=1-0,25 \log (3,5 / 2)=0,939
$$


Table 3. Foundation dimensions and soil parameters of the culvert St: $2+248$.

\begin{tabular}{|c|c|c|c|c|c|}
\hline \multicolumn{6}{|l|}{ Shallow foundation analysis } \\
\hline GWT & & $\mathrm{m}$ & 0.00 & \multirow{8}{*}{\multicolumn{2}{|c|}{$\mathrm{FS}=3.0$}} \\
\hline Internal friction angle & $\phi$ & $\circ$ & 36.00 & & \\
\hline Cohesion & $\mathrm{c}$ & $\mathrm{kPa}$ & 0.00 & & \\
\hline Unit weight & $\gamma$ & $\mathrm{kN} / \mathrm{m}^{3}$ & 21.00 & & \\
\hline Foundation depth & $\mathrm{D}$ & $\mathrm{m}$ & 0.00 & & \\
\hline Foundation width & B & $\mathrm{m}$ & 3.50 & & \\
\hline Foundation length & $\mathrm{L}$ & $\mathrm{m}$ & 45,00 & & \\
\hline Effective stress at foundation level (unloaded) & $\sigma_{0}^{\prime}$ & $\mathrm{kPa}$ & 0.00 & & \\
\hline \multicolumn{6}{|l|}{ Bearing capacity calculations } \\
\hline \multirow{4}{*}{ Bearing capacity factors } & & & $\mathrm{N}_{\mathrm{q}}$ & $\mathrm{N}_{\mathrm{c}}$ & $\mathrm{N}_{\gamma}$ \\
\hline & Han & & 37,75 & 50,59 & 40,05 \\
\hline & Mey & hoff & 37,75 & 50,59 & 44,43 \\
\hline & Vesi & & 37,75 & 50,59 & 56,31 \\
\hline & & & $\mathrm{d}_{\mathrm{q}}$ & $d_{c}$ & $\mathrm{~d}_{\gamma}$ \\
\hline \multirow{3}{*}{ Depth correction factors } & Han & & 1.00 & 1.00 & 1.00 \\
\hline & Mey & hoff & 1.00 & 1.00 & 1.00 \\
\hline & Vesi & & 1.00 & 1.00 & 1.00 \\
\hline & & & $\mathrm{S}_{\mathrm{q}}$ & $\mathrm{S}_{\mathrm{c}}$ & $\mathrm{S}_{\gamma}$ \\
\hline \multirow{3}{*}{ Shape correction factors } & Han & & 1.05 & 1.06 & 0.97 \\
\hline & Mey & hoff & 1.03 & 1.06 & 1.03 \\
\hline & Vesi & & 1.06 & 1.06 & 0.97 \\
\hline \multicolumn{6}{|l|}{ Ultimate bearing capacity (qult) } \\
\hline \multirow{3}{*}{ qult } & \multicolumn{2}{|c|}{ Hansen } & \multicolumn{2}{|l|}{760.62} & $\mathrm{kPa}$ \\
\hline & \multicolumn{2}{|c|}{ Meyerhoff } & \multicolumn{2}{|l|}{896.84} & $\mathrm{kPa}$ \\
\hline & \multicolumn{2}{|c|}{ Vesic } & \multicolumn{2}{|l|}{1069.35} & $\mathrm{kPa}$ \\
\hline \multicolumn{6}{|l|}{ Allowable bearing capacity(qall) } \\
\hline Hansen & \multicolumn{2}{|c|}{238.14} & $\mathrm{kPa}$ & 2,4 & $\mathrm{~kg} / \mathrm{cm}^{2}$ \\
\hline Meyerhoff & \multicolumn{2}{|c|}{280.78} & $\mathrm{kPa}$ & 2,86 & $\mathrm{~kg} / \mathrm{cm}^{2}$ \\
\hline Vesic & \multicolumn{2}{|c|}{238.14} & $\mathrm{kPa}$ & 2,38 & $\mathrm{~kg} / \mathrm{cm}^{2}$ \\
\hline Average & \multicolumn{2}{|l|}{252} & $\mathrm{kPa}$ & 2,6 & $\mathrm{~kg} / \mathrm{cm}^{2}$ \\
\hline
\end{tabular}

In static conditions, bearing capacity $\left(q_{\text {all,Static }}\right)$ is calculated as $2,6 \mathrm{~kg} / \mathrm{cm}^{2}$ 
An embankment of $4 \mathrm{~m}$ height will be placed under the culvert. Under these circumstances, the stressed formed by the embankment must be considered. Therefore, the stress transferred to the foundation is calculated as $\sigma=94 \mathrm{kPa}$. The allowable bearing capacity ( $\mathrm{q}_{\text {all }}$ ) is greater than developed stress in static conditions as shown in Equation (4).

$$
\mathrm{q}_{\mathrm{all}}=4,6 \mathrm{~kg} / \mathrm{cm}^{2}>\sigma_{\max , \mathrm{st} .}=1,0 \mathrm{~kg} / \mathrm{cm}^{2}
$$

The bearing capacity is safe.

\section{Settlement Calculations of Culverts}

Elastic settlement analyses are conducted using theory of elasticity (Mayne and Poulos, 1999) as shown in Equation (5):

$$
S_{e}=\frac{q_{n} B_{e} I_{G} I_{F} I_{E}\left(1-\mu^{2}\right)}{E_{0}}
$$

In Equation 5, $\mathrm{S}_{\mathrm{e}}$ is the elastic settlement, $\mathrm{q}_{\mathrm{n}}$ is the transferred stress, $\mathrm{I}_{\mathrm{G}}, \mathrm{I}_{\mathrm{F}}$, and $\mathrm{I}_{\mathrm{E}}$ are the influence factors, $\mu$ is the Poisson's ratio, and $\mathrm{E}_{0}$ is elasticity modulus.

The settlement calculations are performed with the circular foundation assumption. Therefore, first the equivalent diameter $\left(\mathrm{B}_{\mathrm{e}}\right)$ is calculated in Equation (6).

$$
B_{e}=\sqrt{\frac{4 B L}{\pi}} \text { and } B_{e}=14,16
$$

Influence factors $\mathrm{I}_{\mathrm{G}}, \mathrm{I}_{\mathrm{F}}$, and $\mathrm{I}_{\mathrm{E}}$ are determined through the graphs suggested by Mayne and Poulos (1999). Elastic settlement is expected at conglomerate layer which has the elasticity modulus of $E=50000 \mathrm{kPa}$ determined by the laboratory tests. The settlement analysis is done for $7 \mathrm{~m}(\sim 2 \mathrm{~B})$ depth.

For the calculation of settlement also, the culvert having the largestdimension is considered to be on the safe side. The foundation properties of the culvert St:2+248 are shown in Table 4, and the parameters utilized in settlement calculations are given in Table 5

Table 4. Foundation properties of the culvert St:2+248.

\begin{tabular}{|l|l|l|}
\hline B & Foundation width & $3,5 \mathrm{~m}$ \\
\hline L & Foundation length & $45,0 \mathrm{~m}$ \\
\hline t & Foundation thickness & 0,20 \\
\hline D & Foundation depth & 0,20 \\
\hline Ef & Elasticity modulus of concrete & $2,04 \mathrm{E}+08 \mathrm{kPa}$ \\
\hline
\end{tabular}


Table 5. Parameters utilized in settlement calculations.

\begin{tabular}{|l|l|l|l|}
\hline $\mathrm{q}_{\mathrm{n}}$ & Stress transferred & 80 & $\mathrm{kPa}$ \\
\hline$\mu$ & Poisson's ratio & 0,30 & - \\
\hline $\mathrm{E}_{0}$ & Elasticity modulus & 50 & $\mathrm{Mpa}$ \\
\hline $\mathrm{k}$ & Increase in elasticity modulus & 1000 & $\mathrm{kN} / \mathrm{m}^{2} / \mathrm{m}$ \\
\hline \multirow{2}{*}{$\begin{array}{l}\text { Influence } \\
\text { factors }\end{array}$} & $I_{E}$ & 0,996 & - \\
\cline { 2 - 5 } & $I_{F}$ & 0,988 & - \\
\cline { 2 - 5 } & $I_{G}$ & 0,404 & - \\
\hline
\end{tabular}

The expected total elastic settlement $\left(\mathrm{S}_{\mathrm{T}}\right)$ is calculated as $\mathrm{S}_{\mathrm{T}}=1 \mathrm{~cm}$, and the calculated amount of settlement is within the allowable limits.

\section{RESULTS AND CONCLUSION}

The geotechnical evaluation of the Darbandikhan-Kalar road project was conducted in terms of soil bearing capacity, landslide potential, settlement, and so on. In this context, a drilling program was implemented including drilling, in-situ testing, laboratory testing, and excavation of trial pits in order to obtain geotechnical information. In this context, the following results and conclusions can be drawn from the present study.

- Claystone and conglomeratic levels of Lower Bakhtiari (Mukdadiya) formation constitute the lithological foundation around the project area. Variations from siltstone to conglomerate are observed both horizontally and vertically. They are usually loose textured. So, the upper parts are weathered and fragmented, and a top soil of $0,2-2,0 \mathrm{~m}$ has been formed at the top. Due to top soil, lithological variations and claystone conglomerate boundaries cannot be observed on the field.

- The groundwater level is usually below $30 \mathrm{~m}$ according to the boreholes drilled, except at $\mathrm{BH}-8$, at which it is at a depth of $22 \mathrm{~m}$. Due to the deep groundwater, it is not expected to have any problem arising from water during construction.

- In the boreholes, in each 2-4 m depths, SPT tests were attempted. But due to coarse cobbles and gravels within the conglomerate, SPT tests could be performed only in siltstone and claystone levels.

- 32 disturbed samples (D) and 48 undisturbed (UD) samples were taken from different depths. The disturbed (D) and undisturbed (UD) soil samples taken from the boreholes and test pits during the field study were tested in laboratory. Claystone levels of the Lower Bakhtiari (Mukdadiya) formation constitute the lithological foundation. They are usually loose textured so the upper parts are weathered and fragmented, and a top soil of $0,0-2,0 \mathrm{~m}$ has been formed at the top. Foundation depth must be at least $2 \mathrm{~m}$ because of the filling/ top soil material observed at boreholes.

- The liquid limits of the soils samples vary between $\% 17,8$ and $\% 55,3$. This range means that clay levels of the foundation are usually low plasticity clay. The amount of coarse grained (sand and gravel) soil varies between $\% 4,1$ and \% 43,5. Specific gravity of the clay levels change between 2,59 and 2,79. According to Unified Soil Classification System (USCS), the soil classes are usually CL (low 
plasticity clay with some sand). Depending on the results of standard penetration tests, it has hard andvery stiff consistency.

- The groundwater table is below $30 \mathrm{~m}$, and the foundation units are usually impermeable. So, it is not foreseen to encounter any problem due to the groundwater.

- All chemicals test results of the soil samples are in the acceptable limits.

- Excavated materials cannot be used as infilling material.

\section{ACKNOWLEDGMENT}

The author thanks sincerely the Ministry of Construction and Housing KRG-Iraq family, and especially the engineering staff who support financially and scientifically this article and share their engineering experiences.

\section{REFERENCES}

Bowles, J.E. 1996. Foundation Analysis and Design. 5th Edition, The McGraw-Hill Companies, Inc., New York.

Canoglu, M.C.\&Kurtuluş, B. 2017.Determination of the dam axis permeability for the design and the optimization of grout curtain: an example from Orhanlar Dam (Kütahya-Pazarlar). Periodicals of Engineering and Natural Sciences. 5 (1): 37-43.

DeBeer, E.E. 1965. The scale effect on the phenomenon of the progressive rupture in cohesionless soils. Proceeding of the 6th International Conference on Soil Mechanics and Foundation Engineering. Montreal, QC, Canada. 2 (3): 13-17.

Eldin, N. N. 2002. Road Construction: Materials and Methods. Journal of Environmental Engineering. 128(5): $423-430$.

Hansen, J.B. 1970. A revised and extended formula for bearing capacity. Danish Geotechnical Institute, Bulletin No. 28.

Hany Al-Hmedawy, H.D. 2008.Geomorphological Study of HaurAlHammar and Adjacent Area Southern Iraq Using Remote Sensing Data and GIS Techniques.Geology Department, College Of Science, University Of Baghdad, PhD Thesis, 170p. Baghdad, Iraq.

Mayne, P.V.\&Poulos, H.G. 1999. Approximate displacement influence factors for elastic shallow foundations. Journal of Geotechnical and Geoenvironmental Engineering, 125(6), 453-460.

Meyerhof, G.G. 1963. Some recent research on bearing capacity of foundations. Canadian Geotechnical Journal. 1: 16-26.

Norouzi, N., Mojarab, M.\&Asadi, Z. 2015.A Case Study of Seismic Hazard Analysis at Al-Tajiat and AlZawraa Stadiums in Baghdad/Iraq Region. Arabian Journal for Science and Engineering. 40 (7): 19872002 . 
14 Engineering approaches for road construction projects and determination of geotechnical design parameters: Road network improvement of northern Iraq

Sadek, S., Kaysi, I.\&Bedran, M. 2000.Geotechnical and environmental considerations in highway layouts: an integrated GIS assessment approach. International Journal of Applied Earth Observation and Geoinformation. 2 (3-4): 190-198.

Santoni, R. L., Tingle, J. S. \& Webster, S. L. 2001. Engineering Properties of Sand-Fiber Mixtures for Road Construction. Journal of Geotechnical and Geoenvironmental Engineering. 127 (3): 258-268.

Vesic, A.S. 1975. Bearing capacity of shallow foundations. Foundation engineering handbook. Van Nostrand Reinhold Co., New York.

Younoussa, M., Karfa, T., Raguilnaba, O., Kalsibiri, K., Philippe, B.\&Jean Hugues, T. 2008.Geotechnical, mechanical, chemical and mineralogical characterization of a lateritic gravels of Sapouy (Burkina Faso) used in road construction. Construction and Building Materials. 22 (2): 70-76. 